九州大学学術情報リポジトリ

Kyushu University Institutional Repository

\title{
A Tibetan Stupa within the Flow of Cultural Transformations: The Opportunities and Challenges of Transplanting Buddhist Architecture from Asia to Europe
}

Seegers, Eva

University of Hamburg : Research Fellow | The Numata Center for Buddhist Studies

https://doi.org/10.5109/1806136

出版情報: Journal of Asian Humanities at Kyushu University. 2, pp.67-84, 2017-03. Kyushu University, School of Letters, Graduate School of Humanities, Faculty of Humanities バージョン:

権利関係 : 


\title{
A Tibetan Stupa within the Flow of Cultural Transformations: The Opportunities and Challenges of Transplanting Buddhist Architecture from Asia to Europe
}

\author{
EVA SEEGERS
}

\section{Introduction}

Discussions of the rich and varied forms of the stupa (Sk. stūpa $)^{1}$ are found throughout studies of Asian architecture and Buddhism. The stupa combines Buddhist values and aesthetic concerns in specific ways, making comparisons with other forms of historical architecture difficult. This essay takes up the complexities and significance of Tibetan stupas (Tib. mchod rten), ${ }^{2}$ especially when these outstanding pieces of Buddhist

This essay is the expanded version of a paper presented at the conference Icons of Impermanence: Contemporary Buddhist Art University of British Columbia, Vancouver, Canada, July 6-7, 2012. I thank Canterbury Christ Church University, UK, for the partial funding of my research.

1 Sanskrit words that have entered the English language (such as mantra or stupa) are not shown in italics and appear without diacritic marks. Their proper transliteration is given in brackets when first noted.

2 Tibetan terms have been transliterated according to the Turrel V. Wylie system. The phonetic transcription accords with the THL Simplified Phonetic Transcription of Standard Tibetan by David Germano and Nicolas Tournadre. See Turrel V. Wylie, "A Standard System of Tibetan Transcription," Harvard Journal of Asiatic Studies 22 (1959): 261-67; and David Germano and Nicolas Tournadre, "Simplified Phonetic Transcription of Standard Tibetan," The Tibetan and Himalayan Library (2003), http://www.thlib.org/refer- material culture travel to other continents. It highlights examples wherein non-Buddhists erect them on public grounds and asks questions about relocated traditions. Can the spiritual values, symbolic meanings, and religious significance of the stupa remain unchanged if it is constructed without the motivation of Buddhist beliefs? What new meanings might accrete that may never before have existed in the history of the stupa? This essay is embedded in the ongoing debates over the transformation of art and architecture within cultural flows between Europe and Asia. Based on a case study of a stupa located in a public botanic garden in Germany, it addresses some of the key issues and discussions that arise when an ancient tradition is emplaced in a new cultural context.

The term "culture" is difficult to define, and it is not within the scope of this essay to discuss the various concepts of culture that have developed over time in different academic disciplines. In 1952, American anthropologists Alfred L. Kroeber and Clyde Kluckhohn named 164 definitions of "culture," and since then the

ence/transliteration/\#!essay=/thl/phonetics/ (accessed October 12, 2016). 
number has increased considerably. ${ }^{3}$ One definition that may frame the discussions within this essay defines it as being based on "knowledge, concepts, and values shared by group members . . . culture also consists of the shared beliefs, symbols, and interpretations within a human group."

Culture is generally understood today as a dynamic and discursive exchange or transformation process. Transformation denotes a major or complete change in appearance, form, and meaning. Much excellent work in the contemporary humanities has been devoted to explorations of cultural exchange and adaption. One work in particular clarifies the concerns of the present essay and contributes to my thinking on the general questions posed above: Lieselotte E. Saurma-Jeltsch and Anja Eisenbeiß's The Power of Things and the Flow of Cultural Transformations. ${ }^{5}$ I share their interest in exploring how material artifacts, as well as the imagining of ideas, are exchanged between cultures and historical times, how they are integrated and reassembled, and how they change their meaning in new cultural contexts.

The stupa in question is part of the material culture of the Himalaya, transplanted from Nepal to Germany. Buddhist groups within the geographical region of the Himalaya share traditional knowledge about the ritual use and worship of stupas, a living tradition for many centuries. Some groups know that within the Tibetan Buddhist tradition the stupa is a symbol for the Buddha's dharmakāya (Tib. chos sku) or "truth body," the eternal principle of ultimate truth. All groups know

3 Alfred Louis Kroeber and Clyde Kluckhohn, Culture: A Critical Review of Concepts and Definitions. Harvard University Peabody Museum of American Archaeology and Ethnology Papers 47 (Cambridge, MA: Peabody Museum of American Archaeology and Ethnology, 1952), 41-78.

4 James A. Banks and Cherry A. Mc Gee, eds. Multicultural Education: Issues and Perspectives, $7^{\text {th }}$ ed. (Hoboken, NJ: John Wiley \& Sons, 2010), 8.

5 Lieselotte E. Saurma-Jeltsch and Anja Eisenbeiß, eds., The Power of Things and the Flow of Cultural Transformations: Art and Culture between Europe and Asia (Munich: Deutscher Kunstverlag, 2010).

6 The Digital Himalaya Project Team broadly defines the Himalaya as the region stretching from Ladakh and Kashmir in the west to Arunachal Pradesh and Assam in the east, and from the Tibetan plateau in the north to the foothills in the south. See Sara Shneiderman, Mark Turin, and the Digital Himalaya Project Team, "Digital Himalaya: An Ethnographic Archive in the Digital Age," European Bulletin of Himalayan Research (EHBR) 20, no. 1: 136, http://www.digitalhimalaya.com/publications/ebhr.pdf (accessed November 5, 2016) that Buddhists use stupas as a "receptacle of worship" (Tib. mchod rten). ${ }^{7}$ The majority of Europeans are not Buddhist and thus do not share this traditional knowledge, nor do they share the same understanding of the symbolism and usage of a stupa as people from the $\mathrm{Hi}$ malaya. They will therefore naturally create their own ideas about it.

This essay discusses a religious object, the stupa, which contains relics, mandalas (Sk. mandala), and other precious substances, and whose construction is bound to rituals. In recent years, religious architecture and ritual have become increasingly popular targets of Buddhist Studies inquiries. One valuable example is Yael Bentor's study Consecration of Images and Stupas in Indo-Tibetan Tantric Buddhism, which focuses on a complex Tibetan ritual conducted yearly at the Bodhnāth mahācaitya (great stupa), in Kathmandu. The ritual, in basic terms, consists of a performance of a text written by Khri byang rin po che (1901-81), the late junior tutor of the Dalai Lama. Given its focus on stupa architecture, this essay is also situated within the context of the rare translations of construction manuals, a subfield of Tibetology and Indology. Christoph Cüppers, Leonhard van der Kuijp, and Ulrich Pagel published a richly illustrated handbook authored by the Tibetan scholar sDe srid Sangs rgyas rgya mtsho (1653-1705) around 1687. It contains many examples about how to design, scale, and construct stupas. Pema Dorjee's work Stupa and its Technology: A Tibeto-Buddhist Perspective gives a broad overview on the architectonical background of the Tibetan stupa. He translated Tibetan works on the symbolic meaning and stupa construction manuals authored by $\mathrm{Bu}$ ston Rin chen grub (1290-1364), for instance. ${ }^{8}$ One may

7 On the connection between dharmakāya and stūpa, see Gustav Roth, "Symbolism of the Buddhist Stūpa," in Stupa: Cult and Symbolism, eds. Gustav Roth, Franz-Karl Ehrhard, Kimiaki Tanaka, and Lokesh Chandra (New Delhi: Aditya Prakashan, 2009), 12; Niels Gutschow, "Stūpa: Eine Einführung in Geschichte, Typologie und Symbolik," in Tibet: Klöster öffnen ihre Schatzkammern, ed. Jeong-hee Lee-Kalisch (Essen: Kulturstiftung Ruhr Essen Villa Hügel, 2006), 197; and David L. Snellgrove and Hugh Richardson, A Cultural History of Tibet, $3^{\text {rd }}$ ed. (Bangkok: Orchid Press, 2003), 37.

8 Rin chen grub is an important teacher in the transmission of the 'od zer dri med lha drug, the $4^{\text {th }}$ mandala of the master collection of Sakya materials (rgyud sde kun btus). Tibetan Buddhist Resource Center, Rin chen grub, https://www.tbrc. org/\#!rid=P155 TBRC (accessed February 10, 2017), and Tibetan Buddhist Resource Center, Rgyud sde kun btus. https://www.tbrc. org/\#!rid=W4CZ46035 (accessed February 10, 2017). 
comment, however, on the emic viewpoint of Pema Dorjee: he uncritically writes that some of the sources he refers to can be regarded as the oldest instructions given by Buddha himself.'

Before turning to the specifics of the case study in Germany, I first provide some background on Tibetan stupas, focusing on their history in Nepal. A brief summary of the history of stupas and pagodas in Europe follows, based on my recent study "Visual Expressions of Buddhism in Contemporary Society: Tibetan Stupas built by Karma Kagyu Organisations in Europe."10

\section{The Tibetan Type of Stupa, the Mchod rten in Nepal}

Stupas are among the key visual representations of Buddhism. They evolved from their start in India for more than two thousand years. They originally functioned to enshrine relics of the Buddha. From these ancient reliquaries, stupas have developed into very complex structures with a deep, multilayered symbolism. In Yael Bentor's words:

The stuppa as a whole is conceived as the dharmakaya in its meaning of "corpus of the Teachings." Each part of the stūpa is regarded as a component of the teachings which together constitute the dharma in its entirety. Furthermore, these

9 Yael Bentor, Consecration of Images and Stūpas in Indo-Tibetan Tantric Buddhism (Leiden: E. J. Brill, 1996); Christoph Cüppers, Leonard van der Kuijp, and Ulrich Pagel, eds., Handbook of Tibetan Iconometry: A Guide to the Arts of the 17th Century (Leiden and Boston: Brill, 2012), plates 288-303; and Pema Dorjee, Stupa and its Technology: A Tibeto-Buddhist Perspective (New Delhi: Shri Jainendra Press, 1996), 143-50. The concepts etic and emic were coined by linguist Kenneth L. Pike, who introduced the terms into linguistics and anthropology in 1954. According to Pike, the "etic viewpoint studies behaviour as from the outside of a particular system," while the "emic viewpoint results from studying behaviour as from inside the system." Kenneth L. Pike, Language in Relation to a Unified Theory of the Structure of Human Behavior (Den Haag: Mouton Publishers, 1967), 37. For more information on emic and etic discourse, see Emics and Etics: The Insider/ Outsider Debate, eds. Thomas N. Headland, Kenneth L. Pike, and Marvin Harris (Thousand Oaks: Sage Publication, 1990).

10 Eva Seegers, "Visual Expressions of Buddhism in Contemporary Society: Tibetan Stūpas Built by Karma Kagyu Organisations in Europe," PhD Diss., Canterbury Christ Church University, 2011. components of the teachings comprise the path to enlightenment. ${ }^{11}$

The conception of the stupa as the representation of the dharmakāya, the essential body of the Tathāgata, can be traced to the Pāli Canon. Gustav Roth notes that because of this, the basic architecture of the early stupa was increased in terms of number of parts. When the Indian stupa arrived in the Tibetan cultural realm, likely during the initial dissemination (Tib. snga dar; seventh to eighth century), its architecture had already endured major structural transformations. As described by David L. Snellgrove and Hugh Richardson, the earliest stupas in Tibet presumably consisted of a square platform and five square tapered tiers, upon which a tall dome rested. The superstructure was made from a series of thirteen wheels or rings topped with a half moon, a sun disc, and a drop. In addition to unique monuments like the gigantic $\mathrm{dPal}$ 'khor mchod rten of Gyantse (rGyal rtse), completed around 1427, the standardized group of "Eight Great Location-Caityas" (Sk. așta-mahāsthāna-caityas) became very popular in Tibet. These stupas, or caityas, are of Indian origin and commemorate the Eight Great Events of the historical Buddha, which occurred at eight different locations. ${ }^{12}$ The byang chub mchod rten (Sk. bodhi stūpa; Enlightenment stupa) refers to Buddha's enlightenment in Bodh Gaya and is the type most frequently built (figure 1). The architecture is divided into the throne (Tib. gdan khri); a section

11 Yael Bentor, "In Praise of Stūpas: The Tibetan Eulogy at ChüYung-Kuan Reconsidered," Indo-Iranian Journal 38 (1995): 41. On relic veneration, see John S. Strong, Relics of the Buddha (Princeton and Oxford: Princeton University Press, 2004); and David Germano and Kevin Trainor, Embodying the Dharma: Buddhist Relic Veneration in Asia (New York: State University of New York, 2004). On reliquaries, see Michael Willis, Buddhist Reliquaries from Ancient India (London: British Museum Press, 2000); and Roth, "Symbolism of the Buddhist Stūpa," 12.

12 Snellgrove and Richardson, A Cultural History of Tibet, 89 Erberto Lo Bue and Franco Ricca, The Great Stupa of Gyantse: A Complete Tibetan Pantheon of the Fifteenth Century (London: Serindia Publications, 1993). For the murals inside the stupa, see David Jackson, A History of Tibetan Painting: The Great Painters and Their Traditions (Vienna: Verlag der Österreichischen Akademie der Wissenschaften, 1996), 90-3; and Prabodh Chandra Bagchi, "The Eight Great Caityas and their Cult," The Indian Historical Quarterly 17, no. 2 (1941): 223-35. This group is also known as the "Eight Tathāgata Stupas" (Tib. de bzhin gshegs pa'i mchod rten brgyad), or "Tathāgata stupas of the eight sacred places." See Niels Gutschow, "Stūpa: Eine Einführung in Geschichte, Typologie und Symbolik," 198-99. 


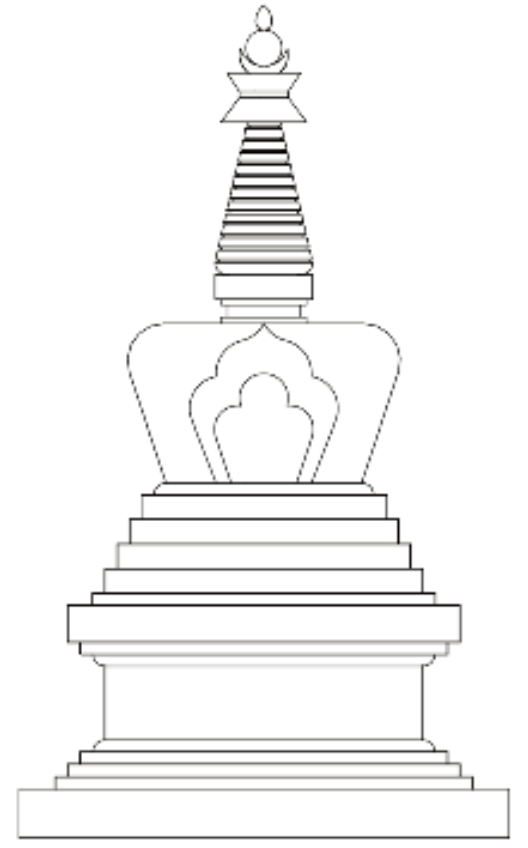

Figure 1. The Tibetan byang chub mchod rten (Sk. bodhi stūpa; Enlightenment stupa) refers to Buddha's enlightenment in Bodh Gayā; it is one of the "Eight Great Location Caityas." Drawing by Michaela Hastenteufel.

with steps that are designed differently; the vase (Tib. bum pa); a square railing on top of the vase (Tib. bre, more commonly known as the [Sk] harmikā); thirteen wheels (Tib. 'khor lo) topped with a rain cover (Tib. char khebs) or parasol (Tib. gdugs); a moon (Tib. zla ba); a sun (Tib. nyi ma); and a jewel peak (Tib. nor bu'i tog). ${ }^{13}$

13 The basic Indian stupa architecture became somewhat extended in the early cave temples of Western India during the first and second centuries $B C E$, when the rather compact body of the early stupa became vertically elongated and its base elevated. Now resting on a cylindrical part, the height of the dome decreased in proportion to the base. Moreover, when Buddhism flourished in the region of ancient Gandhāra (present-day Pakistan and Afghanistan) during the second century $\mathrm{BCE}$ to the sixth century $C E$, unprecedented stupa forms emerged. The chronology is still unclear but there is evidence for the development of specific types that were classified by Heinrich Gerhard Franz. First is the so-called "tower stupa," for example, the Kanișka tower stupa near Peshāwar, which shows a longitudinal extension that would play an important role in the later development of pagodas in East Asia. The second type is the so-called "terrace stupa," such as the Tōp-é-Rustam in Balkh (present-day Baktra in Afghanistan)
The Nepalese have their own history of stupas, or caityas, as they call them. ${ }^{14}$ These buildings were the primary cult objects of the Newar Buddhists from the Licchavi period (ca. 300-80o CE) to the Malla period (ca. $1200-1769 \mathrm{CE}){ }^{15}$ As analyzed in detail by Niels Gutschow, who composed a comprehensive account of the caityas of the Kathmandu valley, the construction of the characteristic Nepalese caitya on the one hand follows the ancient Indian archetype, while on the other hand it follows particular forms developed within this region. The mahācaitya Bodhnāth and Svayambhū are the most significant caitya in Nepalese culture, as is well known.

At what point in history the Tibetans brought their characteristic Tibeto-Buddhist stupa tradition to Nepal is a matter of speculation. It is generally accepted that the first Tibetans settled in the Everest area at the edge of the Tibetan plateau around the sixteenth century, and in my view it is most likely that they built the first stupas there. This point would require more scholarly attention because some stupas, such as the $\mathrm{Ti}$ betan stupas located in the Manang district, have not been researched yet. ${ }^{16}$ Franz-Karl Ehrhard undertook

and the Rawak stupa near Khotan. Here, the hemispherical dome was placed on a square plinth that in some examples also featured staircases leading upwards on all four sides. As explained by Marylin Martin Rhie, in the third century CE the square-based stupa was prevalent in Eastern Central Asia. Heinrich Gerhard Franz, "Stupa and Stupatemple in the Gandharan Regions and Central Asia," in The Stupa: Its Religious, Historical and Architectural Significance, ed. Anna Libera-Dallapiccola (Wiesbaden: Harrassowitz, 1980), 39-79; and Marylin Martin Rhie, Early Buddhist Art of China and Central Asia (2), The Eastern China and Sixteen Kingdoms Period in China and Tumshuk, Kucha and Karashahr in Central Asia (Leiden: Brill, 2002), 637.

14 The Sanskrit terms stūpa and caitya originally held different meaning, but the precise etymologies of both terms are uncertain. Stūpa has been translated as "a knot or tuft of hair, the upper part of head, crest, top, summit," and alternatively "a heap or pile of earth, or bricks etc." The stem stūp- means "to heap up, pile, erect," but there are different opinions if this is the root from which the term stūpa derives. The term caitya has the meaning of being "a funeral monument or pyramidal column containing the ashes of deceased persons, sacred tree (especially a religious fig tree) growing on a mound, hall or temple or place of worship." See Monier Monier-Williams, A Sanskrit-English Dictionary: Etymologically and Philologically Arranged with Special Reference to Cognate Indo-European Languages (Delhi: Motilal Banarsidass, 1974), 1260.

15 Niels Gutschow, The Nepalese Caitya: 1500 Years of Buddhist Votive Architecture in the Kathmandu Valley, Lumbini International Research Institute Monograph Series I (Stuttgart and London: Edition Axel Menges, 1997), 305.

16 The Manang district borders on the Tibetan Autonomous Region to the north, the Mustang district to the west, the Kaski district to 
some stupa research in the remote areas of Nepal by translating a document with the building history of a Tibetan stupa located in Junbesi, Solu-Khumbu in eastern Nepal. The stupa belongs to the "Eight Great Location-Caityas" and was built by members of the Nyang family (Tib. nyang ris) of the Sherpas of eastern Nepal, who trace their origins back to a famous revealer of ancient hidden texts or teachings (Tib. gter ston) of the rNying ma school of Tibetan Buddhism. ${ }^{17}$

Nepalese and Tibetan stupa architecture sometimes influence each other. Niels Gutschow found the first evidence for a Tibetan-style stupa, locally known as bodhicaitya, in Cvasapābāhā, Kathmandu, built in 1701. This type is shaped in the same way as the Tibetan byang chub mchod rten (Enlightenment stupa) but rests on an additional platform. More than two hundred years later, this Nepalese version of the Tibetan stupa became more common in the Kathmandu valley and Gutschow counted eleven caitya of this type on the Svayambhū hill. It should be noted that Nepalese Tulādhar or Mānandhar families, not Tibetans, erected this hybrid type between 1940 and $1979 .{ }^{18}$

In the course of the diaspora, around 1959, the $\mathrm{Ti}$ betans popularized the "Eight Great Location-Caityas" in Nepal by building them around their new exile monasteries. Their numbers increased enormously over the years. The caitya tradition of the Newar continued in parallel. Even today, stonemasons regularly repair the old ones and cast new models for ritual construction and consecration. They also have Tibetan models on offer.

\section{Contemporary Tibetan Stupas in Europe-A Brief Summary ${ }^{19}$}

Tibetan Buddhism became very popular in Europe from the 1970 s as high-ranking Tibetan lamas like the

the south, and the Lamjung district to the east.

17 This revealer was $\mathrm{mNga}$ ' bdag Nyang ral Nyi ma'i 'od-zer. See Franz-Karl Ehrhard, Buddhism in Tibet and the Himalayas: Texts and Tradition (Kathmandu: Vajra Publications, 2013), 181-200, 182, note 1.

18 See Niels Gutschow, The Nepalese Caitya, 302-7.

19 This section briefly summarizes my detailed qualitative survey of contemporary Tibetan stupas belonging to the "Eight Great Location-Caityas," built by Kar ma bKa 'brgyud and Dwags shangs bKa 'brgyud organizations in Europe. Seegers, "Visual Expressions of Buddhism in Contemporary Society," 123-88. $16^{\text {th }}$ Karmapa Rang byung rig pa'i rdo rje (1924-81) started traveling to "the West." A variety of Tibetan Buddhist organizations subsequently emerged and began building stupas from the 1980s. As five major Tibetan groups and several sub-groups constitute the landscape of Tibetan Buddhism in Europe, I cannot easily pin down "the transmission" of "the Tibetan stupa" to Europe. Furthermore, "the Tibetan stupa," as one sharply defined style of religious architecture, does not exist-its measurements, fillings, and rituals are directly bound to the old transmission lines of different Tibetan masters. ${ }^{20}$ I narrowed the scope of my investigation to the Kar ma bKa' brgyud and Dwags shangs bKa 'brgyud organizations, and counted over 220 stupas in sixteen European countries, erected during the past thirty-five years. The number would increase immensely if I included the stupas of all Tibetan organizations in Europe. Undoubtedly, these large numbers demonstrate that stupas are highly important to European Buddhists.

My studies revealed that only a few examples stand on public grounds, and even fewer have been initiated by non-Buddhists; the majority of stupas are built on private grounds at the initiative of Buddhist groups. These stupas follow the traditional key principles of stupa construction, as articulated in manuals or treatises (Tib. mchod rten thig rtsa) that show how to design, scale, and construct stupas. European Buddhists invite a lama specially designated as qualified to carry out spiritual supervision, in Tibetan rdo rje slob dpon (Sk. vajrācārya). This person is responsible for certain major tasks: the geomantic instructions for the examination and preparation of the ground, the exact timing of all steps in the building process, the measurements of the stupa, and the preparation and filling of the treasure chambers inside. The lama is furthermore respon-

20 Eight practice lineages shape Tibetan Buddhism and they can all be traced back to Indian masters. According to Matthew T. Kapstein, these "eight great conveyances that are lineages of attainment" (sgrub brgyud shing rta chen po brgyad) can be traced back to the thirteenth century but have been formulated by sixteenth-century master Prajñāraśmi ('Phreng bo gTer ston Shes rab 'od zer; 1517-84). These include: (1) sNga 'gyur rnying ma; (2) dKa' gdams; (3) Sa skya; (4) Mar pa bKa' brgyud; (5) Shangs pa bKa' brgyud; (6) Zhi byed and gCod; (7) rDo rje rnal 'byor or sbyor ba yan lag drug; and (8) rDo rje gsum gyi bsnyen sgrub. Matthew T. Kapstein, "dDams ngag: Tibetan Technologies of the Self," in Tibetan Literature: Studies in Genre, eds. José Ignacio Cabézon and Roger R. Jackson (Ithaca, NY: Snow Lion Publication, 1996), 278 
sible for the rituals and consecrations before and during the actual construction and knows the exact method of arranging the mandalas inside the central axis, or lifetree (Tib. srog shing). Finally, the lama performs the consecration ritual (Sk. pratistā, Tib. rab gnas) subsequent to the completion of the construction. All these principles make a stupa what it is, namely a symbol for the dharmakāya, which Buddhists use as a "receptacle of worship" (Tib. mchod rten). ${ }^{21}$ Because stupas in Europe take root in a completely different cultural context, they become examples of the creation of new religious and secular spaces.

The most prominent example of this new type of space is the Enlightenment stupa in Benalmádena, located at the Costa del Sol in Spain. With a height of thirty-three meters and a floor area of one hundred square meters, it stands among the largest stupas in Europe. A Tibetan lama from the Himalayan kingdom of Bhutan guided the ritual construction. Together with a German-based Polish architect who specialized in stupa building, the lama designed the most innovative Tibetan stupa so far. The stupa at the Costa del Sol is an outstanding example of the successful transferal of Buddhist visual representations into a new cultural and

21 We find geomantic instructions in the thirty-second chapter of the Vaidurya dkar po (The fundamental treatise on Tibetan astrology and calendrical calculations) by sDe srid Sangs rgyas rgya mtsho (1653-1705). sDe srid Sangs rgyas rgya mtsho, The Vaidūrya dkar po of Sde-srid Sañs-rgyas-rgya-mtsho: The Fundamental Treatise on Tibetan Astrology and Calendrical Calculations (New Delhi: T. Tsepal Taikhang, 1971), vol. 2, fol. 21rl-3or4. A translation into German may be found in Petra Maurer, Die Grundlagen der Tibetischen Geomantie Dargestellt anhand des 32. Kapitels des Vaidūrya dkar po von sDe srid Sangs rgyas rgya mtsho (1653-1705). Ein Beitrag zum Verständnis der Kultur-und Wissenschaftsgeschichte Tibets zur Zeit des 5. Dalai Lama Ngag dbang blo bzang rgya mtsho (1617-1682) (Halle: International Institute for Tibetan and Buddhist Studies, 2009), 188-89.

Unsuitable sites for stupas are, for example, on a grassland with stones; at a place with nāga, scary deities, and 'dre demons; or in a deep gorge at the edge of an earth fissure. Furthermore, a stupa should not be located in the east, for a stupa in the east is thought to destroy a place in the west as the nāga king lingers in the east and is angered if a foundation stone is placed there. Tibetan Buddhist Resource Center, bai DUrya dkar po. https:// www.tbrc.org/\#!rid=W30116 (accessed February 10, 2017).

Tradition stipulates that a special consecration ritual ( $\mathrm{Sk}$. pratistā, Tib. rab gnas), which transform religious objects such as stupas and images into sacred or holy objects, must be conducted when the construction is finished. For more information on contents and consecration, see Bentor, "Literature on Consecration (Rab gnas)," 290-311; and Yael Bentor, "The Content of Stūpas and Images and the Indo-Tibetan Concept of Relics," The Tibet Journal 28, no. 1-2 (2003): 21-48. religious environment. This unique piece of religious architecture has the potential to be the actual starting point of what could be called "Modern Stupa Architecture." The religious significance of stupas in Europe built by Buddhist organizations can be compared to those in Asia, as devotees use them according to tradition (e.g., for circumambulation and participating in area religious activities). ${ }^{22}$

Erecting Tibetan stupas in public parks or other public areas is a relatively new phenomenon in Europe. In the Tibetan cultural realm, it is common for stupas to be constructed at crossroads, alongside streets or in the countryside, which may follow the traditional concept of "liberation through seeing" (Tib. mthong grol), meaning that a stupa is thought to have soteriological efficacy by mere virtue of being viewed. ${ }^{23}$ In this case, the supporters of stupas in public spaces can be thought of as adopting a common Asian tradition common in Europe.

Given that architecture is interwoven with the cloth of cultural life, what conflicts may arise when a Buddhist stupa is built in a mostly non-religious or Chris-

22 This innovative stupa in Andalusia, Spain, built by the architect Wojtek Kossowski, is one of the most important visual representations of Tibetan Buddhist art in Europe. Strikingly, although this stupa adopted some of the principles of the German Bauhaus school and is very modern in shape, it still follows the required traditional principles of stupa construction, which make it a proper object of worship. The former mayor of Benalmádena, who wished to attract more tourists to his region, officially initiated the stupa. European-born Buddhists, following the Karma bKa' brgyud school of Tibetan Buddhism, invited Bhutanese master sLob dpon Tse chu rin po che (1918-2003), the nephew of Shes Rab rdo rje (fl. $18^{\text {th }}$ century). Shes Rab rdo rje carried out a renovation of the Svāyambhū Mahācaitya, on behalf of the king of Bhutan. sLob dpon Tse chu rin po che guided the stupa project from the beginning but died near its completion, and the fourteenth Źwa dmar rin po che (1952-2014) performed the final rab gnas. See Eva Seegers, "The Innovative Stūpa Project in Andalusia, Spain: A Discussion on Visual Representations of Tibetan Buddhist Art in Europe," DISKUS. The Journal of the British Association for the Study of Religions (BASR) 17, no. 3 (2015): 18-39, http://diskus.basr.ac.uk/index.php/DISKUS/article/view/78/67 (accessed November 1, 2016). On Shes Rab rdo rje, see Ehrhard Buddhism in Tibet and the Himalayas: Texts and Tradition, 188, note 7.

23 Liberation from the cycle of existence through contact with the sense faculties is a common practice in the Tibetan cultural realm. As explained by Cathy Cantwell, the Tibetan Book of the Dead (Tib. bar do thos grol) is one of the most well-known examples. It must be read to a dying person in order to liberate him or her through hearing it (Tib. thos grol). Cathy Cantwell, "The Dance of the Guru's Eight Aspects," International Journal of Tantric Studies 1, no. 2 (November 1995), http://asiatica.org/ ijts/vol1_no2/dance-gurus-eight-aspects/ (accessed October 12, 2016). 
tian environment? Transplanting religious monuments from one culture to another may incite cultural clashes or contestation over religious and secular spaces, as I found to be the case in the German city of Hamburg. There, a nine-meter-high stupa was to be erected in a popular park in the center of the city, but the project sparked a debate over religious symbols in public spaces that ultimately led to its termination. The ensuing search for a new site caused a massive protest of residents at another park, and in the end the Buddhist initiators decided to rethink their wish to build a stupa in Hamburg if it was not clearly welcomed.

Austria holds two successful examples of Tibetan stupas erected on public grounds. One stupa was built in 2011 on a prominent site at the Mönchsberg in Salzburg, with a view of the castle, and two years later another stupa was erected on public grounds in the city of Linz. In both cities, European Buddhists together with government representatives found suitable construction sites, agreed on building permissions, and initiated the stupas. Skilled Tibetan lamas spiritually supervised the construction efforts. ${ }^{24}$

Another example can be found in the United Kingdom in the heart of Yorkshire. Bhutanese monks erected a stupa in the garden of Harewood House, one of the National Trust stately homes in England. Constructed under the supervision of the Bhutanese Lama Sonam Chopel, it is the only stupa of this kind in the U.K. and was built in local stone by Yorkshire craftsmen. In 2005, the project concluded with a consecration ceremony presided over by the eminent Bhutanese Lama Baso Karpo. As it is part of a Himalayan garden with Rhododendron species, it shows some similarities to a stupa in Bremen, Northern Germany, to which I will move now.

\section{The Stupa in the Rhododendron Park of Bremen, Germany}

The initiative for the stupa in Bremen originated in the green science center Botanika, a project established in a public park by the city of Bremen in 2003. Today, the Botanika $\mathrm{GmbH}$ is a multifaceted science center aiming

\footnotetext{
24 On the case study carried out in Hamburg, see Seegers, "Visual Expressions of Buddhism in Contemporary Society: Tibetan
} Stūpas Built by Karma Kagyu Organisations in Europe," 189-200. to promote biological diversity and the rhododendron genus to students and the public. It combines Asiatic landscapes and a discovery center with interactive exhibitions.

The stupa is embedded in the Botanika's vision to follow the Convention on Biological Diversity (CBD) and to network with other cultures. The history of the Rhododendron Park traces back to 1935, and today the forty-six-hectare park displays the second largest rhododendron collection in the world. ${ }^{25}$ The Botanika was first intended as a tourist attraction; it was later renovated and extended. Michael Werbeck, former director of the Rhododendron Park and initiator of the Botanika, explained to me that one of the principal ideas behind the concept of the Botanika is to follow certain key points of the CBD, for example, conservation of biodiversity, sustainable usage, and the fair sharing of benefits (i.e., a considerable part of the park's earnings should flow back to the people in the countries from which the primary products originated). ${ }^{26}$ The extraction of biological components from one part of the earth for use elsewhere - in this case, planting rhododendrons from the Himalayas in a German park-are included among these points.

\section{The Stupa as an Exhibit within the Asiatic Landscape}

The basic aim of the project was to create a botanic exhibition that would shed light on not only the flora

\footnotetext{
25 Hartwig Schepker, Rhododendron-Park Bremen. 75 Jahre Blütenpracht (Bremen: Edition Temmen, 2012), 10

26 Michael Werbeck, interview by the author, Bremen, Germany, March 13, 2008. The Convention on Biological Diversity (CBD) was adopted at the United Nations Conference for the Environment and Development (UNCED) in Rio de Janeiro in 1992. This Convention is not confined to nature conservation per se; it also addresses the use-and hence the economic potential-of natural resources as the key to conserving biological diversity. It regulates, furthermore, the cooperation between industrialized countries on the one hand, which possess much of the technical knowledge required to utilize biodiversity; and developing countries on the other, which are home to much of the world's biological diversity and which also possess valuable traditional knowledge about traditional usage forms. The Convention on Biological Diversity is dedicated to preserving the foundations of life for future generations. See Secretary of the Convention on Biological Diversity, Global Biodiversity Outlook 4 - Summary and Conclusions (Montreal: Secretary of the Convention on Biological Diversity, 2014), https://www.cbd.int/gbo/gbo4/gbo4-sum mary-en.pdf (accessed January 10, 2017).
} 


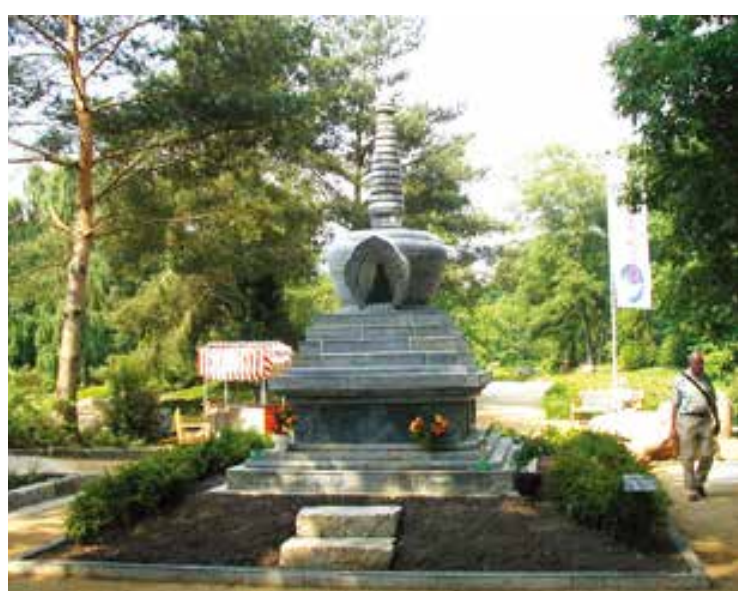

Figure 2. The stupa in Bremen, Germany. Photograph by Olaf Hudecek, 2003.

but also the different cultures of Asia. Project initiators therefore decided to incorporate Asian culture and religion by displaying characteristic features from the region. People from Germany and the Himalayas, they believed, experience their landscapes in unique ways and have different relationships with nature such that the exhibit would be a way to help visitors understand and experience Asian landscapes. ${ }^{27}$

In Bremen, Asiatic landscapes and mountain regions are displayed in an area of four thousand square meters and in three large greenhouses dedicated to the Himalaya, Borneo, and Japan, respectively. The exhibition features characteristic vegetation and cultural elements of each area and contains an extraordinary diversity of flora.

Directly in front of the main entrance of the Botanika, and prefacing the entire exhibition, stands a fourmeter-high Tibetan stupa that was produced in Nepal (figures 2 and 3). Stupas dot the open landscapes of the vast Himalayan range of mountain peaks, which arc across Central Asia, and are one of the key visual representations of the Buddhist tradition which has shaped Himalayan countries to a high degree. Project

27 Michael Werbeck explained the main idea behind the Buddhist exhibits of the Botanika in a press release. Press Release, Senate Press Office, Bremen "Ein besonderer Botschafter für Botanika" (October 2002), http://www.senatspressestelle.bremen.de/ detail.php?id=16517 (accessed December 4, 2016).

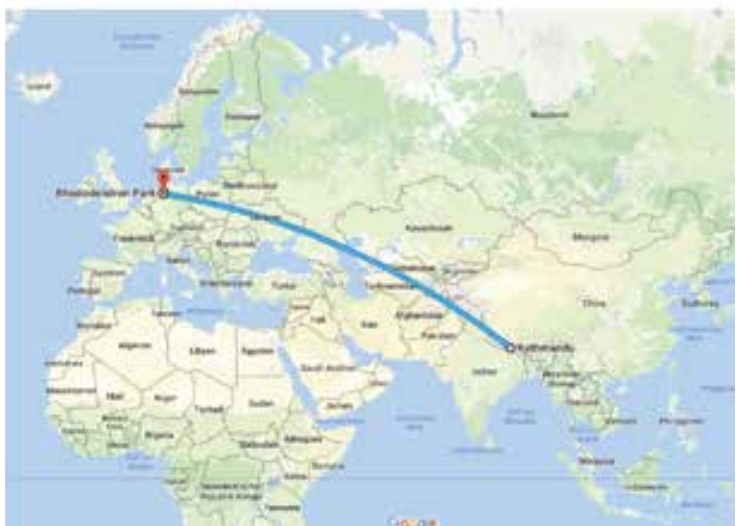

Figure 3. Map of movement for the pre-carved components of a Tibetan Enlightenment stupa transferred from Nepal to Germany in 2003. Image adapted from Google Maps.

initiators determined that such a structure would serve as a perfect complement to the exhibition and decided to place it outside the entrance area. Inside the greenhouse featuring the "Himalayan World," visitors find a statue, hand-made in Kathmandu over a period of thirteen years, of the reclining Buddha in parinirvāna posture. With a length of more than four meters, it is one of the largest bronze statues of a reclining Buddha in Europe. Visitors may rest on a bench in front of the statue and take in the visual splendor of the statue; they can also take part in a living custom found all over the Himalayas of turning a large prayer wheel (Tib. $m a n i$ 'khor lo) containing 168 million printed mantras. Continuing into the greenhouse, visitors circumambulate a mani-wall (Tib. ma ni 'i rdo phung), a wall made of stones or stone slabs decorated with inscriptions of the six-syllable mantra of Avalokiteśvara (om mani padme $h \bar{u} m$ ). Visitors encounter various other details drawn from Himalayan landscapes as well. A small cave containing many tsha tshas (stamped clay images) can be found high in the rocks beside a waterfall, a nod to the well-known Himalayan tradition of placing stamped clay images at sacred sites or other places in order to protect and bless their surroundings. ${ }^{28}$ A Chinese tea

28 The process of making clay tsha tsha is an act of devotion and the finished images are placed inside stupas or at sacred sites. The three main types are figurative, text plaque, and stupa shape. Their creation fulfills a variety of religious or community 
pavilion has also been installed within the exhibition of plants from Vietnam and southern China, and a large seated statue of Shakyamuni Buddha will be integrated into the "Japan World" as part of a project initiated by the Dalai Lama, who offers a statue to each continent in the name of fostering world peace. ${ }^{29}$

The exhibits highlight cultural exchange between Germany and Asia in more than a material sense. During the initial stages of construction, two Tibetan monks living in Nepalese exile were flown to Germany for the ritual construction of the stupa (I outline this below). When the Botanika ran an exhibition of traditional scroll paintings, or thangka (Tib. thang $k a$ ) in 2009, moreover, they invited a Nepali thangka painter to depict a colorful dragon on a rock in the Himalayan greenhouse-now part of the permanent "Himalayan World.” Botanika organizers regularly invite Tibetan monks from Nepal and South India to create sand mandalas of deities like White Tārā (Sk. Sita Tārā, Tib. sgrol dkar), which the monks destroy immediately following the completion ritual as a symbol for the impermanence of all phenomena. The sand is then deposited into the small river flowing through the Rhododendron Park. A diverse program of events such as movies, guided tours, lectures, and meditations centered around Buddhism and Tibet accompanies these yearly events as well. These activities highlight the project's aim to promote lively cultural exchange with the countries of origin-incidentally, they also increase the number of visitors.

purposes. Toni Huber, "Some $11^{\text {th }}$ - Century Indian Buddhist Clay Tablets (tsha-tsha) from Central Tibet," in Tibetan Studies, eds. Ihara Shoren and Yamaguchi Zuiho (Narita: Naritasan Shinshoji, 1992), 493-96.

29 In 1993, the first installation and inauguration of such a Buddha statue was held in New Delhi's Jayanti Park, and was presided over by the Dalai Lama himself. At the time of publication, the German statue is held in New Delhi at the Tibet House, under the spiritual guidance of Tenzin Dhedon, and is scheduled to be transported to Bremen in 2017. The process takes time, because the statue is a gift but its transportation and shelter site must be financed by other parties. See Tibet House, Installation of Buddha Statue at Buddha Jayanti Park (2015), http://www. tibethouse.in/content/installation-buddha-statue-buddha-jayanti-park (accessed December 5, 2016); and Antje Noah-Scheinert, "Friedensbuddha für die Botanika," Weser Kurier, April 24, 2014, http://www.weser-kurier.de/bremen_artikel,-Friedensbuddha-fuer-die-Botanika-_arid,834679.html (accessed December 3 , 2016).

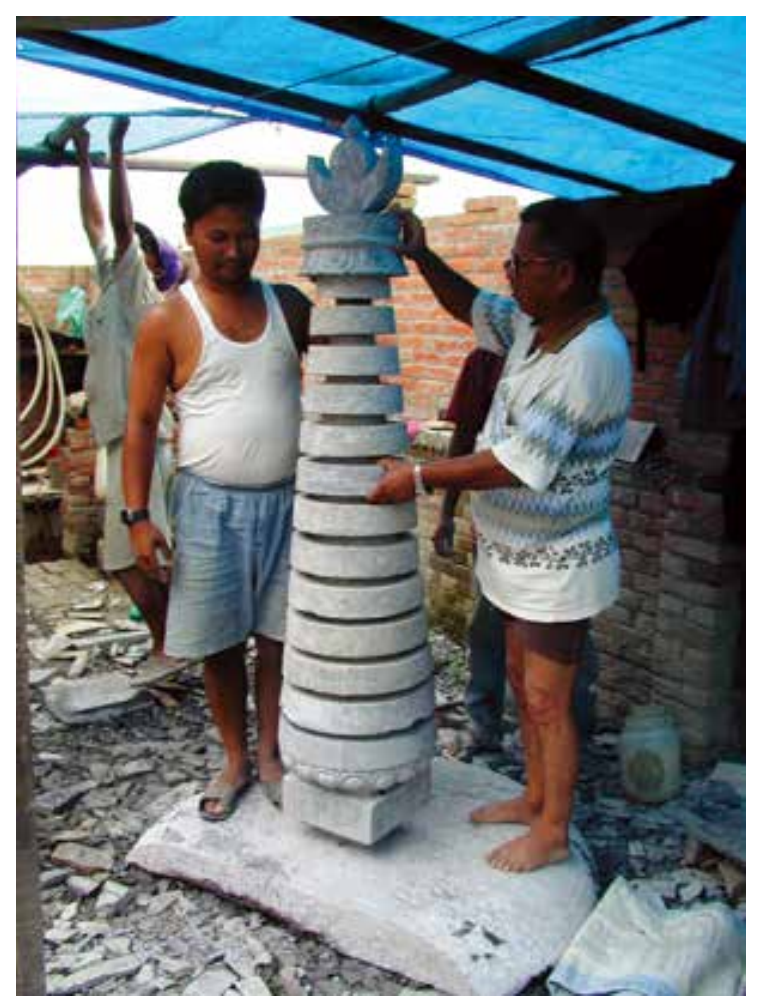

Figure 4. Nepalese stonemasons checking the fit of pre-carved components for the uppermost section of the stupa in Kathmandu, Nepal. Photograph by Holm Triesch, 2003.

\section{Construction History of the Bremen Stupa}

Botanika project initiators ordered a four-meter-high Tibetan-type stupa from two Newar stonemason families in Kathmandu, Nepal (figure 4). The Newar is an important ethnic group in Nepal that has built caityas for centuries. The stupa elements were hand made over a period of eighteen months, packed into separate boxes with an overall weight of approximately eighteen tons, and transported by truck to India before being shipped to Germany. When the individual stupa elements arrived, the initiators realized that without people experienced in stupa construction it would not be possible to create an authentic stupa, only a replica. Dissatisfied with that prospect, they set out to find a proper spiritual guide who could apply the key principles of stupa construction. Few Tibetan lamas endowed with this expertise and either living in Europe or willing to travel to Europe for a single stupa project could be found, how- 


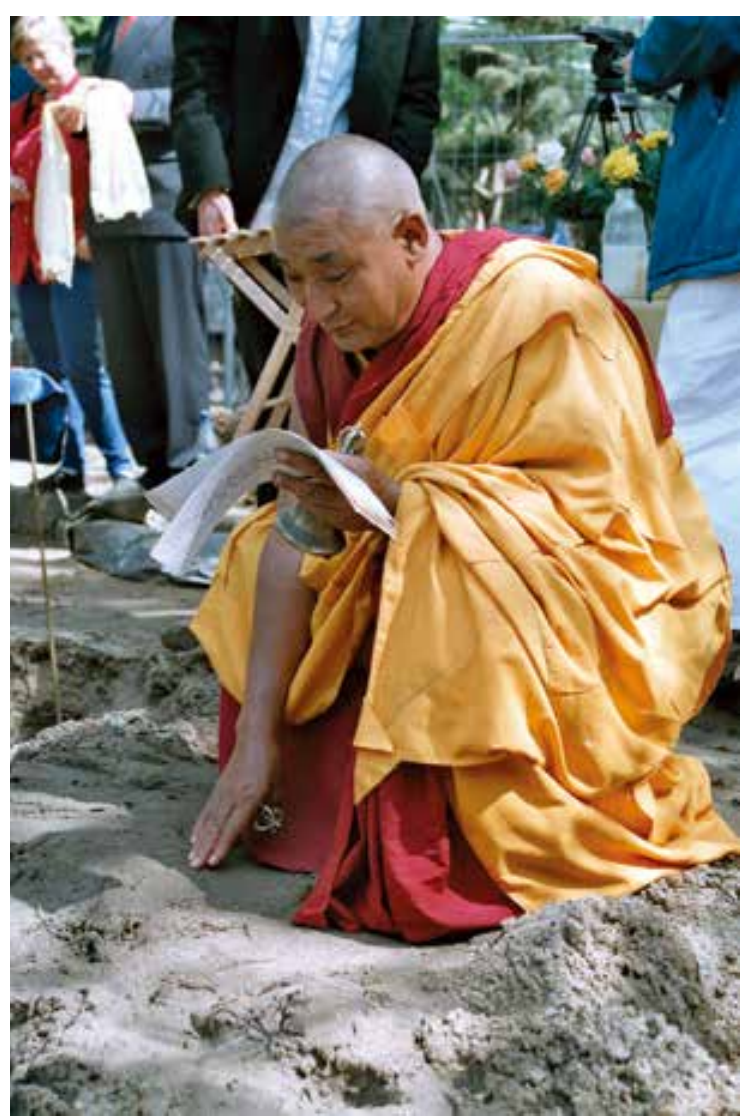

Figure 5. Tibetan lama performing the foundation stone ceremony in the Rhododendron Park in Bremen, Germany. Photograph by Olaf Hudecek, 2003.

ever. In the end, members of the local Diamond Way Buddhist center in Bremen organized and financed the spiritual part of the stupa construction. ${ }^{30}$ Diamond Way Buddhism is a worldwide network of Kar ma bKa' brgyud lay Buddhists who initiated their first European stupa in 1984 in Denmark. ${ }^{31}$ Their experienced stupa architect Wojitek Kossowski was at that time involved in

30 Olaf Hudecek, interview by the author, Bremen, Germany, March $13,2008$.

31 This stupa in Lolland, Denmark was built by bsTan dga' rin po che (1932-2012), who was born in Khams, Eastern Tibet. See Seegers, "Visual Expressions of Buddhism in Contemporary Society: Tibetan Stūpas Built by Karma Kagyu Organisations in Europe," 136. On Diamond Way Buddhism, see "Diamond Way Buddhism," Encyclopaedia of Buddhism, ed. Edward A. Irons (New York: Facts on File, 2008), 162.

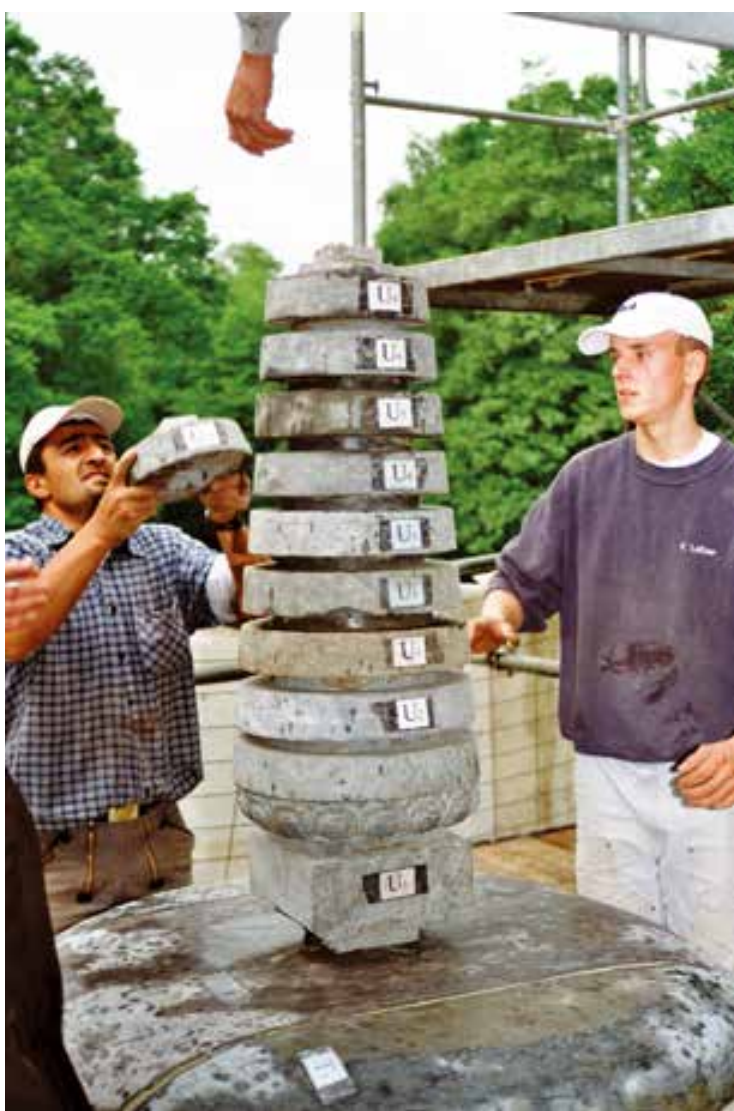

Figure 6. The stupa components carved in Nepal are reassembled in the Rhododendron Park in Bremen, Germany. Photograph by Olaf Hudecek, 2003

his sixteenth stupa project in Europe - the aforementioned thirty-three-meter stupa at the Costa del Sol in Spain. He offered important advice and suggested Lama Kalsang, a Tibetan lama from Kathmandu, to serve as the stupa master (figure 5).

The city of Bremen commissioned a construction company that, together with the Tibetan lama and the German Buddhists, erected the stupa. Figures 6 and 7 reveal the challenging nature of the construction process: using a hand-drawn sketch, the stupa was reassembled on site from stone components pre-carved in Nepal. The stupa contains three chambers that are ritually filled with precious substances, including some fifteen hundred hand-molded tsha tshas. Several specially blessed ritual objects and hundreds of mantra rolls were enclosed inside the stupa as well, arranged 


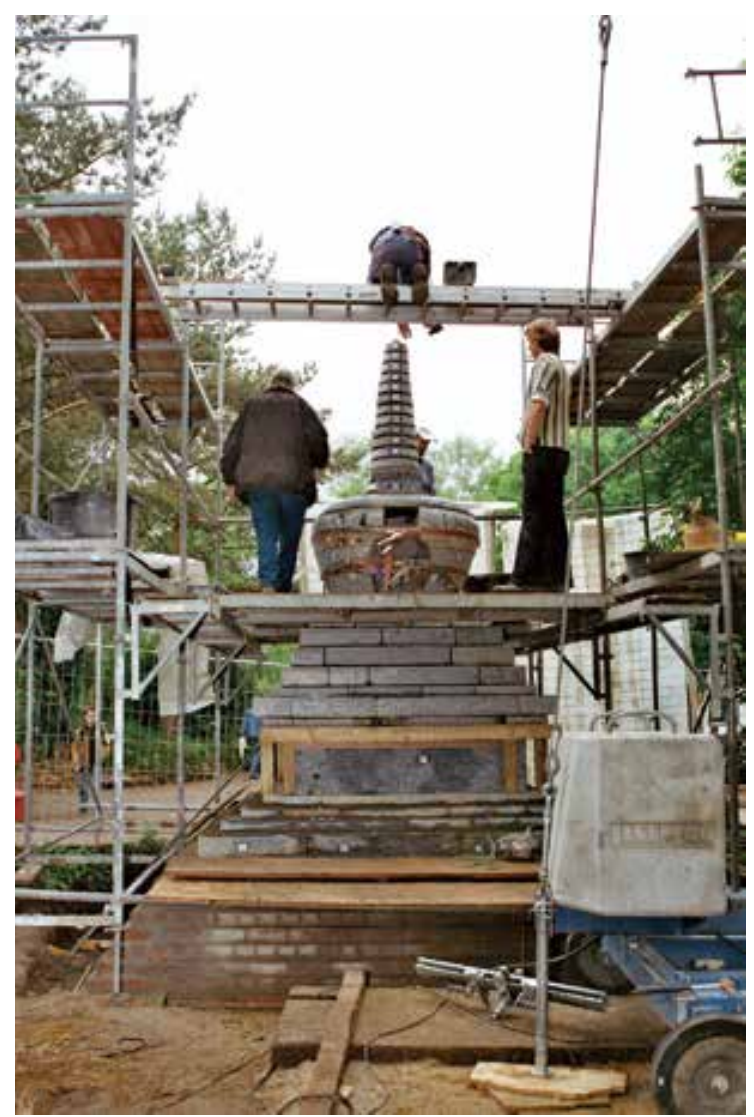

Figure 7. Construction of the stupa in the Rhododendron Park in Bremen, Germany. Photograph by Olaf Hudecek, 2003.

according to traditional instructions (figure 8). One of the most important parts of a stupa, the central axis or life-tree, which normally stretches up to the very top of the stupa, accidentally became much shorter in the Bremen project because the final stone spire lacked the central hole into which the lamas insert the life-tree. On Sunday, May 25, 2003, Lama Kalsang and Lama Ngö Drub performed the final consecration ritual (Tib. rabs gnas).

\section{The Symbolism of the Stupa in this Extraordinary Context}

Essential to the "reading" of religious architecture is the interpretability of symbols and artifacts. A stupa on a crossroad in Kathmandu, for example, has been embedded in the social and religious life of the Nepalese people for centuries. A stupa is part of Buddhist and Asian culture and is therefore interpreted and used accordingly. When a stupa is transmitted from Kathmandu to a park in Germany, it will undoubtedly be interpreted and perceived differently than a Nepalese monument.

The stupa in Bremen represents the byang chub mchod rten type, which can be rendered in English as the Enlightenment stupa (Sk. bodhi stūpa) type. It symbolizes the Buddha's enlightenment in Bodh Gayā and is the most common form of stupa in the Tibetan cultural realm. Tibetan sources explain this stupa as a representation of the Buddha's mind that belongs to a group of well-known objects of worship, which are classified as receptacles of the Buddha's body, speech, and mind (Tib. sku gsung thugs rten). ${ }^{32}$ Images and scroll paintings are considered receptacles of the Buddha's physical body (Tib. sku rten). Texts, books, mantras, seed syllables, and all written forms of the dharma are receptacles for the Buddha's speech (Tib. gsung rten), symbolizing his teachings. The mind of the Buddha (Tib. thugs rten) is represented by a stupa, essentially a container for the relics of the Buddha and those of accomplished masters who represent the Buddha. In short, a stupa represents all the qualities of the Buddha. It is likely that visitors to the Rhododendron Park do not perceive the stupa in this manner, however, but rather develop their own ideas, dependent upon their individual knowledge and the information provided by the local guide. This idea will be discussed below in the section titled "Transformations on Many Levels."

For the initiators of the Botanika, the stupa unites the symbolism and history of Buddhism, a more than two-thousand-year-old world religion - this was their main reason for integrating a stupa into the Asiatic botanical exhibition. By situating the stupa outdoors at the entrance and not directly in the greenhouse with plants, they also added a new function the stupa: indicating to visitors that they are about to enter the world of the $\mathrm{Hi}$ malayas and its religious traditions. I would therefore venture to say that the motivation for building it might be more educational than "spiritual" or Buddhist. After all, the eye-catching stupa and the statue of the reclin32 One source is the Vaidūrya dkar po by Sde-srid Sañs-rgyas-rg-
ya-mtsho mentioned in note 21 . 


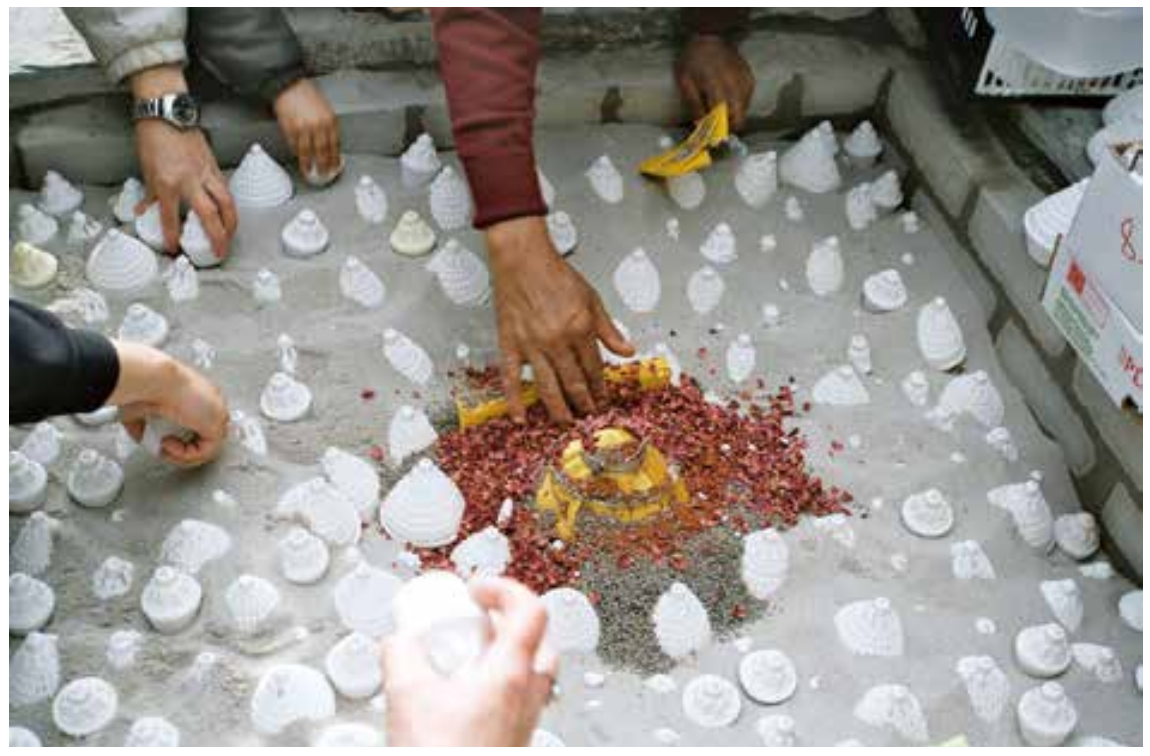

Figure 8. The chambers inside the stupa filled with 1500 tsha tsha and other precious substances. Photograph by Olaf Hudecek, 2003.

ing Buddha inside the huge greenhouse became the principal tourist draws in the Himalayan section.

At the same time, the placement of the stupa at the entrance area where all visitors pass by can also understood as paying heed to the important meaning of stupas as imparting soteriological efficacy by the mere virtue of being visible. As noted above, achieving liberation from the cycle of existence through contact with the sense faculties is a common practice in Tibetan Buddhism. ${ }^{33}$ The Tibetan lamas who supervised the project explained to the initiators that a stupa yields good karma. ${ }^{34}$ Acknowledging this, the initiators decided it might even be beneficial if visiting schoolchildren sat in the vicinity of a stupa and studied. In my view, this kind of statement demonstrates that a non-Buddhist German organization placed trust in the traditional Buddhist concepts connected to a stupa and was able to imagine it as having a positive effect on the local community.

33 See footnote 23.

34 Sources like the Adbhutadharmaparyāya, a Buddhist canonical text about the making of stupas and images, the cult of relics and the merit resulting from them, explain how meritorious the construction and veneration of stupas might be. Yael Bentor "The Redactions of the Adbhutadharmaparyāya from Gilgit," The Journal of the International Association of Buddhist Studies 11, no. 2 (1988): 21-52.

\section{The Stupa and the Garden of Human Rights}

The stupa takes on another level of meaning as well, as part of the Garden of Human Rights, one project of the international organization "INSCRIRE: To write the Human Rights," founded by French artist Françoise Schein at the time of the fall of the Berlin wall. Over many years and in many countries within and without Europe, the organization has conceived and created artistic works and events that highlight human rights principles and cultural diversity. Schein has written inscriptions from the Universal Declaration of Human Rights (1948) in public spaces such as subway stations or cultural institutions as a means of embedding them in the people's awareness. The project connects interest in networks beyond borders with the conviction that this text of the Universal Declaration of Human Rights represents the most important foundation for the social and political coexistence of humanity. ${ }^{35}$ The project, further, adapts its vision to the cultural, social, and urban conditions of the places and countries with which it engages. In 2001, philosopher Barbara Reiter selected the Rhododendron Park in Bremen and de-

\footnotetext{
35 See INSCIRE: To write the Human Rights, "The Garden of the Human Rights. Protected Difference at the Rhododendron's Park in Bremen" (2009), http://www.inscrire.com/ (accessed December 5, 2016).
} 
signed the sub-project "INSCRIRE: Garden of Human Rights," which won the local prize of Agenda 21 after the 1992 conference in Rio. The text of the Human Rights Declaration appears on a continuous ribbon of bronze that winds along the footpaths through the park. The basic idea is that one can walk and read at the same time, reflecting upon the declaration while being in nature. Article 18 on the freedom of religion winds around the pedestal of the stupa. It reads:

\section{Everyone has the right to freedom of thought, con- science and religion; this right includes freedom to change his religion or belief, and freedom, either alone or in community with others and in public or private, to manifest his religion or belief in teaching, practice, worship and observance. ${ }^{36}$}

The bronze band was installed at the same time as the stupa was constructed.

The ribbons establish a connection between the content of the declaration and where they are placed in the park. For example, Article 26 on education leads to the entrance of the Botanika. ${ }^{37}$ Werbeck decided to place the article on religious freedom around the stupa because it represented to him "a symbol for the guarantee of religious freedom, although we are in a Christian country." ${ }^{38}$ Werbeck thus stresses that in Germany, a predominantly Christian country, people are nevertheless open to the symbols of other religions. As already noted in the case of a 2008 stupa project in Hamburg, however. According to city authorities, granting permission for the construction of a Buddhist symbol in a public park would oblige them to allow symbols of other world religions to be presented there as well, including those they did not want. ${ }^{39}$ By integrating the

\footnotetext{
36 The German inscription reads: "Jeder Mensch hat Anspruch auf Gedanken-, Gewissens- und Religionsfreiheit; dieses Recht umfasst die Freiheit, seine Religion oder seine Überzeugung zu wechseln, sowie die Freiheit, seine Religion oder seine Überzeugung allein oder in Gemeinschaft mit anderen, in der Öffentlichkeit oder privat, durch Lehre, Ausübung, Gottesdienst und Vollziehung von Riten zu bekunden." For the English text, see United Nations Human Rights (1948), Universal Declaration of Human Rights: General Assembly resolution 217 A (III), http:// www.un-documents.net/a3r217a.htm (accessed December 5, 2016).

37 Barbara Reiter, email interview by the author, December 5, 2016 38 Werbeck, interview.

39 On the Hamburg case study, see Seegers, "Visual Expressions of Buddhism in Contemporary Society," 189-200. For more details on human rights and Buddhism, see, for example, Peter Harvey,
}

stupa into a project for human rights, the Bremen stupa became an icon for religious freedom and interreligious dialogue. These levels of meaning do not exist in the Himalayas and point to the context-dependent nature of the stupa's symbolism.

\section{Some Conflicts \& Political and Economic Aspects}

Some conflict and dispute arose surrounding the Botanika in Bremen, but according to Werbeck the central issue had nothing to do with the stupa or other Buddhist exhibits; rather, several influential citizens voiced concern that the Rhododendron Park was becoming a tourist trap. Residents living close to the park complained about additional streams of tourists or more cars parking in front of their homes. Fortunately, these protests have subsided.

Although no specific protests have been raised concerning the stupa in Bremen there have been vehement discussions on whether prayer flags could be hung in the Botanika's entrance area. Some residents and local businesspeople interpreted the Tibetan prayer flags, which were visible from a great distance, as "pro-Tibet" signs. One of the initiators of the stupa project also served as a representative of a politically active group aiming to improve the situation in Tibet (Tibet Initiative Germany). His commitment to constructing a Tibetan stupa could be interpreted as supporting the interests of Tibet, but he denied this when asked. Certain parties were nevertheless deeply concerned about potential negative effects on trade relations, since the city of Bremen trades extensively with China. In response to this argument, Werbeck responded that he did not find it especially convincing because there is also a Chinese pavilion in the greenhouse of the Botanika. Both Chinese and Tibetan cultures, he noted, are well represented. ${ }^{40}$

This dispute highlights a valid point, however. Once, when presenting my research on Tibetan stupas in Europe at a conference, an agitated Chinese researcher-colleague came forward and claimed that the construction of a Tibetan stupa in Europe is to

An Introduction to Buddhist Ethics: Foundation, Values and Issues (New York: Cambridge University Press, 2000), 18-121. 40 Werbeck, interview. 
be understood as a pro-Tibet activity. It would be far preferable to build a Chinese pagoda, the man argued, because China is many times larger and much more influential than Tibet, which is just a tiny province within that country-one need only compare China's population of 1.3 billion to Tibet's five million. The building of Tibetan stupas in Europe constituted for this man a symbol of "Western" hostility towards China. Although his suggested symbolism (i.e., Western support for an oppressed Tibet) is new, stupas have traditionally been used to make political statements, beginning with King Aśoka's stupa-building project in the third century в which was partially intended to assert his political authority. Whether building stupas today could be construed as an aggressive and hostile act, rather than a symbol of peace and harmony, is a topic requiring further research.

\section{Transformations on Many Levels}

This paper takes as its central theme the relocation of a traditional religious icon into a new, non-religious setting. It investigates the layered meanings of a transplanted Himalayan stupa through a case study in Bremen, Germany. This final section examines in more detail the multi-layered transformations involved in the process:

(1) The stupa in the public Rhododendron Park provides an excellent example of cultural exchange on many levels. Newar stonemasons pre-carved the many components of the stupa in Nepal, but instead of following the tradition of Nepalese caityas they designed it according to Tibetan Buddhist tradition. Here we can discern a first-level combination of "cultures" or traditions. We also see cross-cultural contact in the joint efforts of Tibetan lamas and German Buddhists to care for the stupa's religious rituals and the depositing of relics into the stupa. The stupa is today part of the Rhododendron Park's estate and is maintained by German Buddhists - actors from other countries (or "cultures") are no longer involved. The stupa nevertheless still plays an ambassadorial role in representing the $\mathrm{Hi}$ malayan region and acting as an intermediary between European and Asian cultures.

Let us consider briefly the intriguing idea that a Buddhist stupa or pagoda represents more "culture" than religion. I believe this notion emerged in the field of landscape architecture as an approach to erecting Asian architectural structures in Europe without the motivation of Buddhist beliefs. By the middle of the eighteenth century, it had become fashionable to install decorative buildings in the gardens and estates of the landed gentry. A new style of architecture that excited particular interest was the so-called chinoiserie - a seventeenth- and eighteenth-century style of interior design, furniture, pottery, textiles, and garden design that represented a Western idea of Chinese design.

Chinoiserie drew on reports from travelers who felt inspired by the architecture of the "Orient" and subsequently sought to shape many gardens in a similar style. In the United Kingdom, the well-known connoisseur Richard Bateman (1705-73) installed a number of chinoiserie buildings in his garden at Windsor as early as the 1730s, while the gardens at Stowe, Shugborough, and Virginia Water also incorporated Chinese elements. By 1750, chinoiserie had spread widely and expanded to include other influences, both exotic and gothic. One of the oldest landscape pagodas in existence in Europe is the impressive fifty-meter-high Chinese pagoda in Kew Gardens, London, which the British architect William Chambers (1726-96) designed based on the ideals of chinoiserie in 1761. Another early example in Europe is the Japanese tower erected in 1905 by French architect Alexandre Marcel (1860-1928) near Brussels, Belgium, based on the ideals of Japonism. Marcel gained notoriety for his remarkable pagoda in the Rue de Babylone in Paris and his replica of parts of Angkor Wat for the Cambodian pavilion during the 1900 World Exhibition in Paris. ${ }^{41}$ Both the Japanese tower near Brussels and the Chinese pagoda in Kew Gardens, London were, however, commissioned and authorized by the royal houses of Belgium and England, respectively. These circumstances, along with a contemporary predilection among the upper class for Orientalism, indicate that the motivation for erecting such monuments was

\footnotetext{
41 After many years in China, Chambers published his book Designs of Chinese Buildings in 1757. He settled in England became Princess Augusta's (1768-1840) official architect, and designed more than two dozen buildings for Kew. The Belgian King Leopold II (1835-1909) requested Marcel to build the huge Japanese tower, which was finished in 1905, and a Chinese pavilion at Laken close to Brussels. For more information, see John Harris, Sir William Chambers: Architect to George III (London: Yale University Press, 1996) and Ray Desmond, Kew: The History of the Royal Botanic Gardens (London: Royal Botanic Gardens, 2007).
} 
less religious than imperialistic. Since the publication of Edward Said's Orientalism in 1987, the asymmetrical power relationship in the dialogical discourse between "the West" and "the East" has been brought to the forefront of cross-cultural studies. Orientalism, for Said, denotes the Western style of dominating, restructuring, and having authority over the East. Orientalism and other works by Said sparked a wide variety of controversy and criticism. ${ }^{42}$

Said's critique of the Western interpretation or creation of the Orient has been extended to criticism of the construction of Tibet as a land of Western fantasy, as outlined in Donald Lopez's Prisoners of Shangrila. ${ }^{43}$ Lopez clearly applies Said's insights (as well as those of Foucault and Bourdieu) for his analysis of the ways in which Tibet has been appropriated in Western culture: "For Lopez, Tibet as it is understood in the West is less a country with its own history and socio-cultural arrangements than a construction, a mythical hyper-reality created by and for Westerners." ${ }^{44}$ Tibet is not perceived on its own terms but as an "object of fantasy." This romanticized view of Tibet raises the quandary of how best to understand the erection of a Tibetan stupa in the "Himalayan World" section of a public park. Is a "romanticist" building a stupa in order to create a "little Tibet" or is there a deeper meaning? It is important here to distinguish between the project's initiators and its users or recipients, a matter I will return to shortly.

In this discussion of cultural transformation, it seems necessary to point out that artifacts, tools, and other tangible elements alone do not account for a culture's entire essence; we must also consider how members of the group interpret, use, and perceive them. Cultural exchange today stands for the sharing of different values and knowledges on the same level, eye to eye. The stupa in Bremen, embedded in the vision of the Botanika to follow the Convention on Biological Diversity and to network with other cultures, provides a good example of this.

\footnotetext{
42 Edward Said, Orientalism (New York: Pantheon, 1978). For critical discourse on Said, see, for example, Edward Said's Translocations: Essays in Secular Criticism, eds. Tobias Döring and Mark Stein (New York and London: Routledge, 2012).

43 Donald S. Lopez, Jr., Prisoners of Shangrila: Tibetan Buddhism and the West (Chicago: University of Chicago Press, 1998).

44 George Dreyfus, "Are We Prisoners of Shangrila? Orientalism, Nationalism, and the Study of Tibet," Journal of the International Association of Tibetan Studies 1 (2005): 2.
}

(2) Installing a stupa in a public park in northern Germany creates a multi-layered territory. The Enlightenment stupa, located the entrance area of a greenhouse complex, introduces visitors to the "Himalayan World." It is also visible from the terrace of the nearby restaurant. A single site in this case represents, on the one hand, a landscape exhibition with a Himalayan object and, on the other hand, a newly marked religious space that houses a sacred object.

(3) Specific actors with specific agendas encounter the stupa. We must distinguish between Buddhist practitioners who understand and use the stupa according to traditions and explanations from Buddhist teacher and general non-Buddhist viewers who may know nothing at all about Tibetan Buddhism. Non-Buddhists may perceive the stupa as an exotic artifact enticing them to explore the Asian landscapes inside the greenhouses. Buddhists, in contrast, recognize the stupa as an object of worship and may show their respect by circumambulating it and making good wishes. The mixing of interests need not be mutually exclusive, however, and may in fact complement each other. Buddhists, beyond their religious inclinations, may be inspired to visit the landscape exhibition and thus focus on more cultural aspects of the stupa. Non-Buddhists may wish to learn more about Buddhism and open up to the stupa's religious meaning. Observed from the Buddhist perspective, moreover, the stupa fulfills its visual efficacy and soteriological function by simply being seen, regardless of visitors' religious denominations (or lack thereof).

Contemporary Tibetan teachers often emphasize the difference between Tibetan culture and teachings on the essence of Buddhism. For example, Źwa dmar rin po che (1952-2014) invited his Western students to follow the example of the Tibetan masters who transferred Buddhism from India to Tibet and integrated it into their local customs and culture-he entreated his students to do the same. ${ }^{45}$ During many interviews, I found that Buddhists who build stupas in Europe understand them basically as Buddhist symbols for enlightenment and not as cultural monuments transplanted from the Himalayas to Europe. Some practitioners may nevertheless retain a romantic view on

45 Źwa dmar rin po che, "Die Übertragung des Buddhismus in den Westen. Ein Vortrag in Kempten, September 1992," Kagyü Life 11 (1993): 13-6. 
stupas and the special atmosphere created by these monuments. Some non-Buddhists may associate everything from Tibet with mass media imagery (i.e., the Dalai Lama, who was awarded the Nobel Peace Prize). For these people, it is probably much easier to understand a stupa as a "peace monument," as many Buddhist organizations do. ${ }^{46}$

If a non-Buddhist sees a stupa in a public park dedicated to the exhibition of Himalayan plants, as in Bremen or Yorkshire, he or she may interpret it correctly as a representative and typical object for this region or as a support for the exhibited plants. If an information board informs visitors that it is a Tibetan Buddhist stupa originating in the Himalayas, some visitors may interpret it as an idealization of Tibet, even if the initiators had an entirely different motivation for its construction. To counteract possible misinterpretations, initiators and clients should provide information about the general meaning of stupas and the reasons for constructing a stupa at this particular site. In Graz, Austria, for example, a glass panel inscribed with basic information is displayed and residents from the Buddhist center talk to passersby who show interest. Yearly open-house days, when school classes are invited to visit, are also occasions to provide information. Unless such measures are taken, the stupa in Bremen might be little more than a romantic symbol of a foreign Buddhist culture, where prayer flags flap in the wind, Buddha images recline in rock niches, red-robed monks and nuns scatter sand mandalas, and Nepalese painters create dragons on rocky walls.

(4) The Buddhist stupa is a very flexible architectural structure, designed to represent key principles of Buddhist doctrine but able to adapt other levels of meanings. Like a transparent gemstone reflecting the colors of its surrounding area, a religion adopts the "colors" of the cultures it is practiced in. Applied to the case at hand, the construction of an Asian stupa in Europe implies the adoption of local circumstances - the significance of the stupa in Bremen extends far beyond

46 For example, the Japanese Nippozan Myōhōji Buddhist Order which erects peace pagodas around the world. There exist more than eighty peace pagodas in Japan, India, Ladakh, Sri Lanka, Europe and the USA. See Jacqueline I. Stone, "Nichiren's Activist Heirs. Sōka Gakkai, Risshō Kōseikai, Nippozan Myōhōji", in Action Dharma: New Studies in Engaged Buddhism, eds. Damien Keown, Charles S. Prebish, and Christopher Queen (New York: Routledge Curzon, 2003), 63-94 religious and cultural aspects to economic, political and sociological themes. As this paper has examined, in addition to traditional religious meaning the stupa in Bremen represents Himalayan culture in a broad sense. What makes this stupa unique, however, are its additional references to the contemporary topic of human rights. Because of its integration into the "Garden of Human Rights" project, it also constitutes an icon of religious freedom. This combination of symbolism is uncommon and innovative, marking the stupa as a model case for what may happen if a religious object is relocated to a non-religious setting and incorporated into several overlapping local projects. The layered meanings of the transplanted stupa show an extraordinary multi-functionality which we do not find in Asia. Still, the stupa in Bremen is an exceptional case. Most stupas newly built in Europe are initiated by Buddhist groups and organizations for their religious value. As I have analyzed elsewhere, these "religious stupas" are primarily used for Buddhist practice but occasionally take on contemporary meanings. For example, Tibetan Buddhists erected a stupa on the grounds of the Institut Tibétain Yeunten Ling in Huy, Belgium and dedicated it to world peace with the hope that the stupa would shield the area from a nearby nuclear power plant. This new interpretation demonstrates again the flexible functions of a stupa.

\section{Concluding Remarks}

Within the flow of cultural exchanges and transformations, the stupa may open to new interpretations without losing its traditional significance. In other words, a stupa can take on new levels of meaning in order to meet the local needs of the context and the people involved while still retaining its spiritual values, symbolic meanings, and religious significance.

\section{Bibliography}

Bagchi, Prabodh Chandra. "The Eight Great Caityas and their Cult." The Indian Historical Quarterly 17, no. 2 (1941): 223-35.

Banks, James A. and Cherry A. McGee Banks, eds. Multicultural Education: Issues and Perspectives ( ${ }^{\text {th }}$ ed.). Hoboken, NJ: John Wiley \& Sons, 2010. 
Bentor, Yael. "The Content of Stūpas and Images and the Indo-Tibetan Concept of Relics." The Tibet Journal 28, no. 1-2 (2003): 21-48.

- Consecration of Images and Stūpas in Indo-Tibetan Tantric Buddhism. Leiden: E. J. Brill, 1996.

__. "Literature on Consecration (Rab gnas)." In Tibetan Literature: Studies in Genre. Edited by José Ignacio Cabezón and Roger R. Jackson, 290-311. Ithaca, New York: Snow Lion Publication, 1996.

. "In Praise of Stūpas: The Tibetan Eulogy at ChüYung-Kuan Reconsidered.” Indo-Iranian Journal 38 (1995): 31-54.

."The Redactions of the Adbhutadharmaparyayya from Gilgit." The Journal of the International Association of Buddhist Studies 11, no. 2 (1988): 21-52.

Bue, Erberto Lo and Franco Ricca. The Great Stupa of Gyantse: A Complete Tibetan Pantheon of the Fifteenth Century. London: Serindia Publications, 1993.

Cantwell, Cathy. "The Dance of the Guru's Eight Aspects." International Journal of Tantric Studies 1, no. 2 (November 1995). http://asiatica.org/ijts/vol1_no2/dance-guruseight-aspects/ (accessed October 12, 2016).

Cüppers, Christoph, Leonard van der Kuijp, and Ulrich Pagel, eds. Handbook of Tibetan Iconometry: A Guide to the Arts of the 17th Century. Leiden and Boston: Brill, 2012.

Desmond, Ray. Kew: The History of the Royal Botanic Gardens ( $2^{\text {nd }} e d$.). London: Royal Botanic Gardens, 2007.

sDe srid Sangs rgyas rGya mtsho. The Vaidūrya dkar po of Sde-srid Sains-rgyas-rgya-mtsho: The Fundamental Treatise on Tibetan Astrology and Calendrical Calculations, vol. 2. New Delhi: T. Tsepal Taikhang, 1971.

Döring, Tobias and Mark Stein, eds. Edward Said's Translocations: Essays in Secular Criticism. New York and London: Routledge, 2012.

Dorjee, Pema. Stupa and its Technology: A Tibeto-Buddhist Perspective. New Delhi: Shri Jainendra Press, 1996.

Dreyfus, George. "Are We Prisoners of Shangrila? Orientalism, Nationalism, and the Study of Tibet." Journal of the International Association of Tibetan Studies 1 (2005): 1-22. http://www.thlib.org/collections/texts/jiats/\#!jiats=/o1/ dreyfus (accessed January 3, 2017).

Ehrhard, Franz-Karl. Buddhism in Tibet and the Himalayas: Texts and Tradition. Kathmandu: Vajra Publications, 2013.

Franz, Heinrich Gerhard. "Stupa and Stupatemple in the Gandharan Regions and Central Asia." In The Stupa. Its Religious, Historical and Architectural Significance. Edited by Anna Libera-Dallapiccola, 39-79. Wiesbaden: Harrassowitz, 1980 .
Germano, David and Kevin Trainor. Embodying the Dharma: Buddhist Relic Veneration in Asia. New York: State University of New York, 2004.

Germano, David and Nicolas Tournadre. "Simplified Phonetic Transcription of Standard Tibetan." The Tibetan and Himalayan Library (2003): 1-13. http://www.thlib. org/reference/transliteration/\#! essay=/thl/phonetics/ (accessed January 12, 2017).

Gutschow, Niels. "Stūpa: Eine Einführung in Geschichte, Typologie und Symbolik.” In Tibet: Klöster öffnen ihre Schatzkammern. Edited by Jeong-hee Lee-Kalisch, 197215. Essen: Kulturstiftung Ruhr Essen Villa Hügel, 2006.

. The Nepalese Caitya: 1500 Years of Buddhist Votive Architecture in the Kathmandu Valley (Lumbini International Research Institute Monograph Series I). Stuttgart and London: Edition Axel Menges, 1997.

Harris, John. Sir William Chambers: Architect to George III. London: Yale University Press, 1996.

Harvey, Peter. An Introduction to Buddhist Ethics: Foundation, Values and Issues. New York: Cambridge University Press, 2000.

Headland, Thomas N., Kenneth L. Pike, and Marvin Harris, eds. Emics and Etics: The Insider/ Outsider Debate. Thousand Oaks: Sage Publication, 1990.

Huber, Toni. "Some $11^{\text {th }}$-Century Indian Buddhist Clay Tablets (tsha-tsha) from Central Tibet." In Tibetan Studies. Edited by Shoren Ihara and Zuiho Yamaguchi, 493-96. Narita: Naritasan Shinshoji, 1992.

INSCRIRE: To write the Human Rights. "The Garden of the Human Rights. Protected Difference at the Rhododendron's Park in Bremen" (2009). http://www.inscrire.com/ (accessed December 5, 2016).

Irons, Edward A., ed. Encyclopaedia of Buddhism. New York: Facts on File, 2008.

Jackson, David. A History of Tibetan Painting: The Great Painters and Their Traditions. Vienna: Verlag der Österreichischen Akademie der Wissenschaften, 1996.

Kapstein, Matthew T. "dDams ngag: Tibetan Technologies of the Self." In Tibetan Literature: Studies in Genre. Edited by José Ignacio Cabézon and Roger R. Jackson, 275-89. Ithaca, NY: Snow Lion Publication, 1996.

Kroeber, Alfred Louis and Clyde Kluckhohn. "Culture: A Critical Review of Concepts and Definitions." Harvard University Peabody Museum of American Archaeology and Ethnology Papers 47. Cambridge, MA: Peabody Museum of American Archaeology and Ethnology, 1952.

Lopez, Donald S. Jr. Prisoners of Shangrila: Tibetan Buddhism and the West. Chicago: University of Chicago Press, 1998. 
Maurer, Petra. Die Grundlagen der Tibetischen Geomantie Dargestellt anhand des 32. Kapitels des Vaidūrya dkar po von sde srid Sangs rgyas rgya mtsho (1653-1705). Ein Beitrag zum Verständnis der Kultur- und Wissenschaftsgeschichte Tibets zur Zeit des 5. Dalai Lama Ngag dbang blo bzang rgya mtsho (1617-1682). Halle: International Institute for Tibetan and Buddhist Studies, 2009.

Monier-Williams, Monier. A Sanskrit-English Dictionary: Etymologically and philologically arranged with special reference to cognate Indo-European languages. Reprint edition. Delhi: Motilal Banarsidass, 1974.

Pike, Kenneth L. Language in Relation to a Unified Theory of the Structure of Human Behavior. Den Haag: Mouton Publishers, 1967.

Press Release, Senate Press Office, Bremen. "Ein besonderer Botschafter für Botanika." October 2002. http://www.senatspressestelle.bremen.de/detail.php?id=16517 (accessed December 4, 2016).

Rhie, Marylin Martin. Early Buddhist Art of China and Central Asia (2), The Eastern China and Sixteen Kingdoms Period in China and Tumshuk, Kucha and Karashahr in Central Asia. Leiden: Brill, 2002.

Roth, Gustav. "Symbolism of the Buddhist Stupa." In Stupa: Cult and Symbolism. Edited by Franz-Karl Ehrhard, Kimiaki Tanaka, and Lokesh Chandra, 9-33. New Delhi: Aditya Prakashan, 2009.

Said, Edward. Orientalism. New York: Pantheon, 1978.

Saurma-Jeltsch, Lieselotte E. and Anja Eisenbeiß, eds. The Power of Things and the Flow of Cultural Transformations: Art and Culture between Europe and Asia. Munich: Deutscher Kunstverlag, 2010.

Schepker, Hartwig. Rhododendron-Park Bremen. 75 Jahre Blütenpracht. Bremen: Edition Temmen, 2012.

Secretary of the Convention on Biological Diversity. Global Biodiversity Outlook 4 - Summary and Conclusions. Secretary of the Convention on Biological Diversity: Montréal, 2014. https://www.cbd.int/gbo/gbo4/ gbo4-summary-en.pdf (accessed January 10, 2017).

Seegers, Eva. "The Innovative Stūpa Project in Andalusia, Spain: A Discussion on Visual Representations of Tibetan Buddhist Art in Europe." DISKUS. The Journal of the British Association for the Study of Religions (BASR) 17, no. 3 (2015): 18-39.

. "Two Stūpas of Princess Wengcheng: A Comparative Study on Two Ancient Terrace Stūpas in Eastern Tibet." Journal of Comparative Cultural Studies in Architecture. Architecture and Conservation: Tibet 8 (2015): 52-63. - "Visual Expressions of Buddhism in Contemporary Society: Tibetan Stūpas Built by Karma Kagyu Organisa- tions in Europe." PhD diss., Canterbury Christ Church University, 2011.

Shneiderman, Sara, Mark Turin, and the Digital Himalaya Project Team. "Digital Himalaya: An Ethnographic Archive in the Digital Age." European Bulletin of Himalayan Research (EHBR) 20, no. 1: 136-41. http://www.digitalhimalaya.com/publications/ebhr.pdf (accessed November 5, 2016).

Snellgrove, David L. and Hugh Richardson. A Cultural History of Tibet ( $3^{\text {rd }}$ ed). Bangkok: Orchid Press, 2003.

Stone, Jacqueline I. "Nichiren's Activist Heirs. Sōka Gakkai, Risshō Kōseikai, Nippozan Myōhōji." In Action Dharma: New Studies in Engaged Buddhism. Edited by Damien Keown, Charles S. Prebish, and Christopher Queen, 63-94. New York: RoutledgeCurzon, 2003.

Strong, John S. Relics of the Buddha. Princeton and Oxford: Princeton University Press, 2004.

Tibetan Buddhist Resource Center. bai DUrya dkar po. https://www.tbrc.org/\#!rid=W30116 (accessed February, 10 2017).

- Rin chen grub. https://www.tbrc.org/\#!rid= $=\mathrm{P}_{155}$ TBRC (accessed February 10, 2017).

- Rgyud sde kun btus. https://www.tbrc. org/\#!rid=W4CZ46035 (accessed February 10, 2017).

Tibet House. Installation of Buddha Statue at Buddha Jayanti Park. 2015. http://www.tibethouse.in/content/installation-buddha-statue-buddha-jayanti-park (accessed December 5, 2016).

United Nations Human Rights. Universal Declaration of Human Rights: General Assembly resolution 217 A (III). 1948. http://www.un-documents.net/a3r217a.htm (accessed December 5, 2016).

Willis, Michael. Buddhist Reliquaries from Ancient India. London: British Museum Press, 2000.

Wylie, Turrel V. "A Standard System of Tibetan Transcription." Harvard Journal of Asiatic Studies 22 (1959): 261-67. 